\title{
The Hemopexin Domain of Matrix Metalloproteinase-9 Activates Cell Signaling and Promotes Migration of Schwann Cells by Binding to Low-Density Lipoprotein Receptor- Related Protein
}

\author{
Elisabetta Mantuano, ${ }^{1,2}$ Gen Inoue, ${ }^{1,3}$ Xiaoqing Li, ${ }^{1}$ Kazuhisa Takahashi, ${ }^{3}$ Alban Gaultier, ${ }^{2}$ Steven L. Gonias, ${ }^{2}$ and \\ W. Marie Campana ${ }^{1}$ \\ Departments of ${ }^{1}$ Anesthesiology and ${ }^{2}$ Pathology, University of California, San Diego, La Jolla, California 92093-0629, and ${ }^{3}$ Department of Orthopedic \\ Surgery, Graduate School of Medicine, Chiba University, Chiba 260-8670, Japan
}

\begin{abstract}
Low-density lipoprotein receptor-related protein (LRP-1) is an endocytic receptor for diverse proteins, including matrix metalloproteinase-9 (MMP-9), and a cell-signaling receptor. In the peripheral nervous system (PNS), LRP-1 is robustly expressed by Schwann cells only after injury. Herein, we demonstrate that MMP-9 activates extracellular-signal-regulated kinase (ERK1/2) and Akt in Schwann cells in culture. MMP-9 also promotes Schwann cell migration. These activities require LRP-1. MMP-9-induced cell signaling and migration were blocked by inhibiting MMP-9-binding to LRP-1 with receptor-associated protein (RAP) or by LRP-1 gene silencing. The effects of MMP-9 on Schwann cell migration also were inhibited by blocking the cell-signaling response. An antibody targeting the hemopexin domain of MMP-9, which mediates the interaction with LRP-1, blocked MMP-9-induced cell signaling and migration. Furthermore, a novel glutathione-S-transferase fusion protein (MMP-9-PEX), which includes only the hemopexin domain of MMP-9, replicated the activities of intact MMP-9, activating Schwann cell signaling and migration by an LRP-1-dependent pathway. Constitutively active MEK1 promoted Schwann cell migration; in these cells, MMP-9-PEX had no further effect, indicating that ERK1/2 activation is sufficient to explain the effects of MMP-9-PEX on Schwann cell migration. Injection of MMP-9-PEX into sciatic nerves, $24 \mathrm{~h}$ after crush injury, robustly increased phosphorylation of ERK1/2 and Akt. This response was inhibited by RAP. MMP-9-PEX failed to activate cell signaling in uninjured nerves, consistent with the observation that Schwann cells express LRP-1 at significant levels only after nerve injury. These results establish LRP-1 as a cell-signaling receptor for MMP-9, which may be significant in regulating Schwann cell migration and physiology in PNS injury.
\end{abstract}

Key words: Schwann cell; peripheral nerve; proteinase; cell migration; hemopexin; phosphatidylinositol 3 kinase; ERK/MAP kinase

\section{Introduction}

Cell migration involves the integrated function of cell-signaling factors, integrins, proteins that regulate dynamic actin assembly, and proteinases that model extracellular matrix (ECM) (Lauffenberger and Horwitz, 1996). In development and in injury to the peripheral nervous system (PNS), Schwann cells migrate toward axonal signals, where they differentiate by ensheathing and/or myelinating axons and form a framework for nerve regeneration (Bunge et al., 1986). In spinal cord injury, Schwann cells also migrate to lesion sites and assist in sustaining axons (Blesch and Tuszynski, 2007). Many factors that promote glial survival, such

Received July 1, 2008; revised Sept. 17, 2008; accepted Sept. 25, 2008.

This work was supported by National Institutes of Health Grants R01 NS057456 (W.M.C.) and R01 NS054571 (S.L.G.) and The Uehara Memorial Foundation (G.I.).

Correspondence should be addressed to Dr. W. Marie Campana, Department of Anesthesiology, University of California, San Diego, 9500 Gilman Drive, MTF 443, La Jolla, CA 92093-0629. E-mail: wcampana@ucsd.edu. DOI:10.1523/JNEUROSCI.3053-08.2008

Copyright $\odot 2008$ Society for Neuroscience ～0270-6474/08/2811571-12\$15.00/0 as neuregulin (NRG-1), also function in Schwann cell migration (Yamauchi et al., 2008).

LDL receptor-related protein (LRP-1) is a $600 \mathrm{kDa}$, two-chain transmembrane receptor in the LDL receptor gene family (Strickland et al., 2002). LRP-1 was first identified as a receptor for apolipoprotein E (Kowal et al., 1989) and $\alpha_{2}$-macroglobulin (Strickland et al., 1990); however, LRP-1 is currently recognized as an endocytic receptor for diverse ligands, including proteinases, growth factors, and ECM proteins (Strickland et al., 2002). LRP-1 also regulates cell signaling in response to specific ligands, including tissue-type plasminogen activator (tPA), apolipoprotein E, and activated $\alpha_{2}$-macroglobulin (Hu et al., 2006; Hayashi et al., 2007; Padmasekar et al., 2007; Mantuano et al., 2008). The mechanism probably involves tyrosine phosphorylation of the LRP-1 $\beta$-chain and binding of signaling adaptor-proteins (Gotthardt et al., 2000; Kinoshita et al., 2001; Su et al., 2002).

The effects of LRP-1 on cell migration are cell type-specific. Described mechanisms include LRP-1-initiated cell signaling and regulation of urokinase-type plasminogen activator receptor (uPAR), thrombospondin, or Mac1 (Webb et al., 2000; Orr et al., 
2003; Cao et al., 2006). LRP-1 is abundantly expressed in Schwann cells in PNS injury and is important for Schwann cell survival (Campana et al., 2006). LRP-1silencing decreases the basal level of activity of phosphatidylinositol 3-kinase (PI3K) and Akt, which form a wellestablished anti-apoptotic signaling cascade in Schwann cells (Campana et al., 1999; Weiner and Chung, 1999; Campana et al., 2006). However, the ligands that bind to LRP-1 and control cell signaling in the injured PNS remain unknown.

Matrix metalloproteinase 9 (MMP-9) is an LRP-1 ligand (Hahn-Dantona et al., 2001), which is expressed by Schwann cells at increased levels in PNS injury (La Fleur et al., 1996; Shubayev and Myers, 2002). The function of MMP-9 in PNS injury is not completely understood; however, MMP-9 is reported to regulate ECM remodeling and cell migration through tissue boundaries (Springman et al., 1990; Koyama et al., 2008). In this study, we demonstrate that MMP-9 activates cell signaling and promotes Schwann cell migration by binding to LRP-1. These activities do not require the MMP-9 proteinase active-site, but instead are mediated by the MMP-9 hemopexin domain (MMP-9PEX), which is known to bind to LRP-1 (Van den Steen et al., 2006). The ability of MMP-9-PEX to activate extracellularsignal-regulated kinase (ERK1/2) is sufficient to explain the increase in Schwann cell migration in vitro. MMP-9-PEX also activates cell signaling in vivo, when injected into sciatic nerves. This response is observed only after nerve injury, when Schwann cells express abundant LRP-1 (Campana et al., 2006) and adopt a migratory phenotype (Ide, 1996; Torigoe et al., 1996). Receptor-associated protein (RAP), which inhibits ligand-binding to LRP-1 (Willnow et al., 1996; Strickland et al., 2002), blocked the effects of MMP-9-PEX on cell signaling in injured sciatic nerves. These studies establish Schwann cell LRP-1 as a cell-signaling receptor for MMP-9, which may regulate Schwann cell migration and physiology in PNS injury.

\section{Materials and Methods}

Reagents. Pharmacological antagonists LY294002 (a PI3K inhibitor) and PD098059 (the MEK1 inhibitor) were purchased from Calbiochem. Recombinant human MMP-9, MMP-2 and murine NRG-1 were purchased from R\&D Systems. Recombinant human erythropoietin (Epo) was purchased from Johnson and Johnson. Fibronectin was purchased from Sigma. Constructs encoding constitutively active MEK1 (CA-MEK) and green fluorescent protein (pEGFP) are described previously (Nguyen et al., 1999). Rabbit polyclonal antibodies specific for phosphorylated Akt, phosphorylated ERK1/2, total ERK1/2, and HRP-conjugated secondary antibody were purchased from Cell Signaling Technologies. A monoclonal antibody that recognizes total Akt was also purchased form Cell Sig- naling Technologies. RAP was expressed as a glutathione-S-transferase (GST)-fusion protein (GST-RAP) as previously described (Herz et al., 1991). As a control, we expressed GST in bacteria transformed with the empty vector, pGEX-2T. GST-specific antibody was purchased form GE Healthcare. Mouse monoclonal antibody that binds specifically to the hemopexin domain of human MMP-9 was purchased from Abcam.

Cell culture. Schwann cells were isolated from the sciatic nerves of 1-d-old Sprague Dawley rats and further selected from fibroblasts using fibronectin-specific antibody and rabbit complement, as previously described (Campana et al., 1998). The final preparations consisted of $98 \%$ Schwann cells, as determined by immunofluorescence for $\mathrm{S} 100$, which is a specific Schwann cell marker. Primary cultures of Schwann cells were 

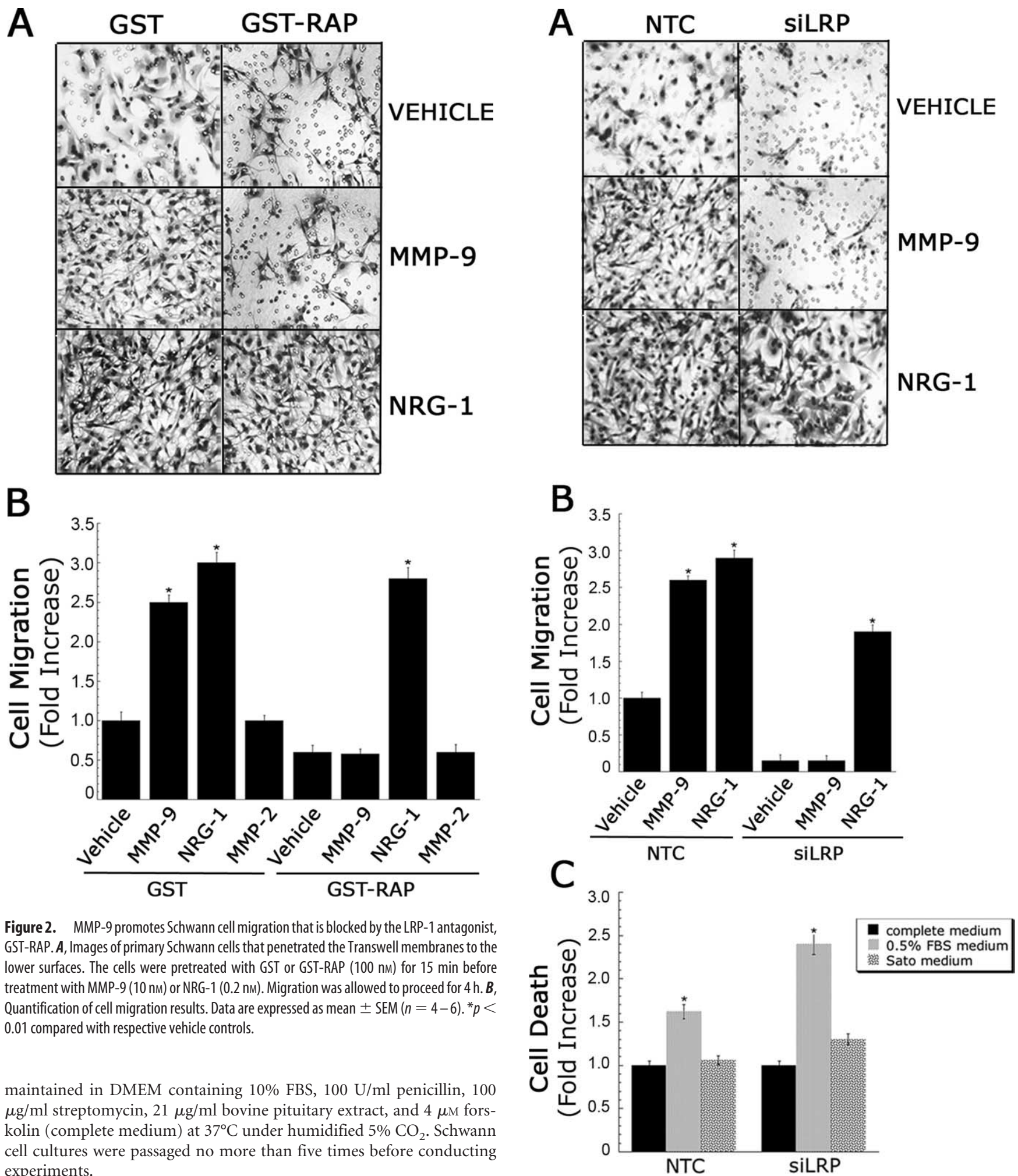

Figure 2. MMP-9 promotes Schwann cell migration that is blocked by the LRP-1 antagonist, GST-RAP. A, Images of primary Schwann cells that penetrated the Transwell membranes to the lower surfaces. The cells were pretreated with GST or GST-RAP (100 nM) for 15 min before treatment with MMP-9 $(10 \mathrm{~nm})$ or NRG-1 $(0.2 \mathrm{~nm})$. Migration was allowed to proceed for $4 \mathrm{~h} . \boldsymbol{B}$ Quantification of cell migration results. Data are expressed as mean \pm SEM $(n=4-6) .{ }^{*} p<$ 0.01 compared with respective vehicle controls.

maintained in DMEM containing 10\% FBS, $100 \mathrm{U} / \mathrm{ml}$ penicillin, 100 $\mu \mathrm{g} / \mathrm{ml}$ streptomycin, $21 \mu \mathrm{g} / \mathrm{ml}$ bovine pituitary extract, and $4 \mu \mathrm{M}$ forskolin (complete medium) at $37^{\circ} \mathrm{C}$ under humidified $5 \% \mathrm{CO}_{2}$. Schwann cell cultures were passaged no more than five times before conducting experiments.

LRP-1 gene silencing. The previously described rat LRP-1-specific siRNA (CGAGCGACCUCCUAUCUUUUU) (Campana et al., 2006) and nontargeting control (NTC) siRNA were purchased from Dharmacon. Primary cultures of Schwann cells $\left(1 \times 10^{6}\right)$ were transfected with LRP-1-specific siRNA ( $25 \mathrm{~nm}$ ) or with NTC siRNA ( $25 \mathrm{~nm}$ ) by electroporation using the Rat Neuron Nucleofector Kit (Amaxa). The degree of LRP-1 gene silencing was $92-95 \%$ at $24-72 \mathrm{~h}$ postelectroporation as determined by quantitative PCR ( $\mathrm{PPCR}$ ), immunoblot analysis, and RAP ligand blotting as previously described (Campana et al., 2006). Cell signaling and migration experiments were performed between 24 and $36 \mathrm{~h}$ after introduction of siRNAs.

Figure 3. LRP-1 gene silencing in Schwann cells blocks basal cell migration and migration in response to MMP-9. A, Images of Schwann cells, transfected with NTC- or LRP-1-specific siRNA, which migrated to the underside surface of Transwell membranes. The cells were treated with MMP-9 (10 nM) or NRG-1 ( $0.2 \mathrm{~nm})$. Migration was allowed to proceed for $4 \mathrm{~h} . B$, Quantification of cell migration results. Data are expressed as mean $\pm \operatorname{SEM}(n=6) .{ }^{*} p<0.01$ compared with respective vehicle controls. C, Schwann cell death was measured using the Cell Death ELISA in cells transfected with NTC siRNA or LRP-1-specific siRNA, after culturing for $4 \mathrm{~h}$ in complete medium (10\% FBS), 0.5\% FBS-containing medium, or Sato medium. ${ }^{*} p<0.05$ compared with complete media. 

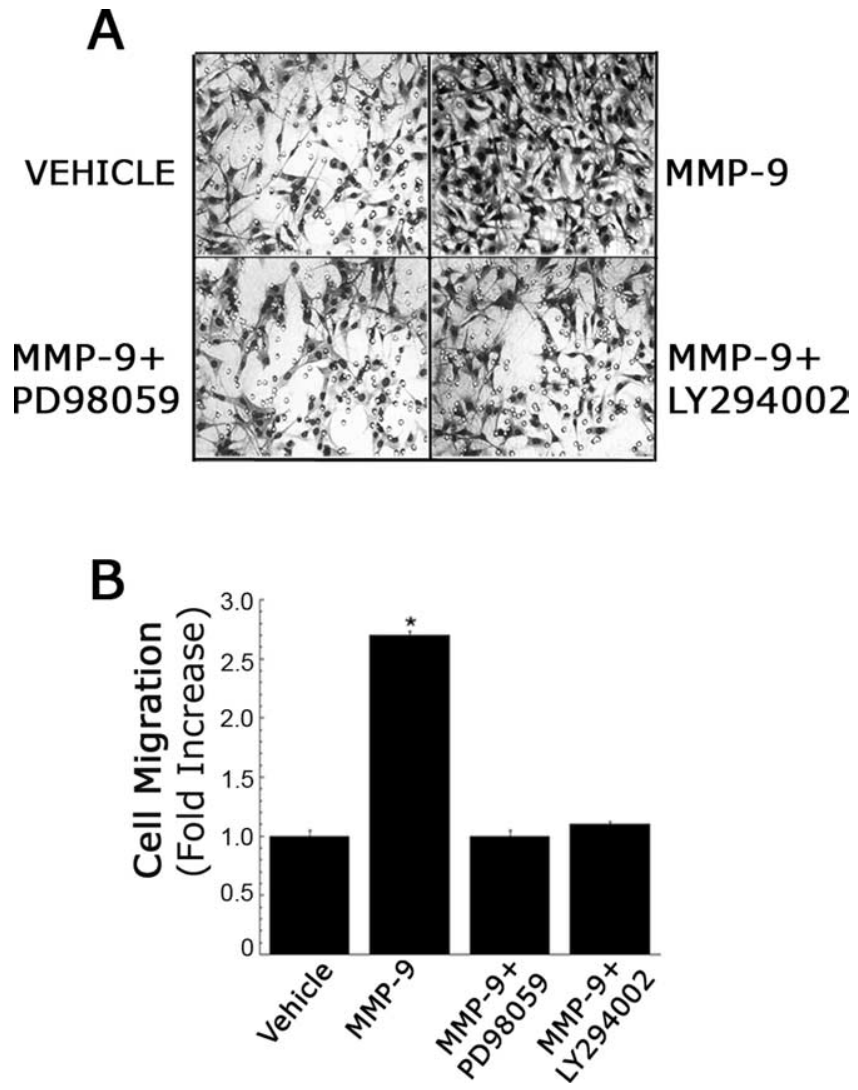

Figure 4. MMP-9-induced Schwann cell migration is blocked by inhibitors of MEK 1 and PI3K. $A$, Images of Schwann cells that penetrated to the underside surface of Transwell membranes. The cells were pretreated with PD98059 $(50 \mu \mathrm{M})$ or LY294002 $(20 \mu \mathrm{M})$ for $15 \mathrm{~min}$ before the addition of MMP-9 (10 nM). Migration was allowed to proceed for $4 \mathrm{~h}$. B, Quantification of cell migration results. Data are expressed as mean \pm SEM $(n=4),{ }^{*} p<0.01$ compared with respective vehicle controls.

Construction of a GST-fusion protein encoding the MMP-9 hemopexin domain. A 573 bp sequence corresponding to the hemopexin domain in the full-length human MMP-9 cDNA (Origene) was amplified by PCR. The sense primer was engineered with an internal EcoRI site (5'GGAATTCGATGCCTGCAACGTGAACATCTTCGACG-3') and the antisense primer was engineered with an internal XhoI site (5'CCGCTCGAGTTAGCACTGCAGGATGTCATAGGTCACG-3') to allow cloning into pGEX-5X-1 (GE Healthcare). Primers were synthesized by ValueGene. Amplification was performed using Sigma REDTaq DNA Polymerase. The integrity of the final construct was confirmed by sequence analysis (Eton Bioscience).

The intact GST fusion protein (MMP-9-PEX) and GST were expressed in BL21-Gold competent cells (Stratagene) by induction with isopropyl1 -thio- $\beta$-D-galactopyranoside. Bacteria were treated with lysozyme and sonicated. MMP-9-PEX was partially purified by selective detergent extraction (Webb et al., 1998) and then purified to homogeneity by chromatography on glutathione-Sepharose (Mantuano et al., 2008). All GSTfusion proteins and GST were subjected to endotoxin decontamination.

Activation of Akt and ERK1/2. Primary cultures of Schwann cells were plated in T25 flasks in serum-containing medium and cultured until $\sim 85 \%$ confluent. The cultures then were transferred to serum-free medium (SFM) and maintained for $1 \mathrm{~h}$ before adding either a positive control stimulant or various concentrations of MMP-9 or MMP-9-PEX (0.5-100 nM). Incubations with these reagents were conducted for 10 min unless otherwise described. In some cases, cells were pretreated with GST-RAP (100 nM), GST (100 nM), PD098059 (50 $\mu \mathrm{M})$, LY294002 (20 $\mu \mathrm{M})$, MMP-9-PEX specific antibody, or control IgG for $15 \mathrm{~min}$. The cells were then rinsed twice with ice-cold PBS. Cell extracts were prepared in RIPA buffer (PBS with 1\% Triton X-100, 0.5\% sodium deoxycholate,
$0.1 \%$ SDS, proteinase inhibitor mixture and sodium orthovanadate). The protein concentration in cell extracts was determined by bicinchoninic acid assay. An equivalent amount of cellular protein $(50 \mu \mathrm{g}$ per lane) was subjected to $10 \%$ SDS-PAGE and electrotransferred to nitrocellulose membranes. The membranes were blocked with $5 \%$ nonfat dry milk in Tris- $\mathrm{HCl}$ buffered saline, $\mathrm{pH} 7.4$ with Tween 20 and incubated with the primary antibodies according to the manufacturer's recommendations. The membranes were washed and treated with horseradish peroxidise-conjugated secondary antibodies for $1 \mathrm{~h}$. Immunoblots were developed using enhanced chemiluminescence (GE Healthcare). Blots were scanned (Cannoscan) and densitometry was performed by National Institutes of Health Image.

Cell migration assays. Migration of Schwann cells was studied using 6.5 $\mathrm{mm}$ Transwell chambers with $8 \mu \mathrm{m}$ pores (Corning Costar) as described previously (Nguyen et al., 1999). The bottom surface of each membrane was coated with $10 \mu \mathrm{g} / \mathrm{ml}$ fibronectin. We selected fibronectin as the substratum because after peripheral nerve injury, fibronectin expression is induced to provide a provisional matrix for nerve regeneration (Akassoglou et al., 2002). Schwann cells in Sato medium supplemented with 1 $\mathrm{mg} / \mathrm{ml}$ bovine serum albumin (BSA) (Bottenstein and Sato, 1980) were treated with vehicle, NRG-1 (0.2 nM), MMP-9 (10 nM), MMP-2 (10 nM), or MMP-9-PEX ( $10 \mathrm{nM})$ for $10 \mathrm{~min}$ at $37^{\circ} \mathrm{C}$. In some cases, the cells were pretreated with LY29004 (20 $\mu \mathrm{M})$, GST-RAP (100 nM), GST (100 nM), or PD098059 $(20 \mu \mathrm{M})$ before adding other factors. Reagents were added at the same concentration to the medium in the Transwells. The bottom chamber contained $10 \%$ FBS. Cells $\left(10^{5}\right)$ were transferred to the top chamber of each Transwell and allowed to migrate at $37^{\circ} \mathrm{C}$ in $5 \% \mathrm{CO}_{2}$. After $4 \mathrm{~h}$, the upper surface of each membrane was cleaned with a cotton swab. The membranes then were stained with Diff-Quik (DadeBehring). The number of cells on the bottom surface of each membrane was counted. Each condition was studied in triplicate. Four fields were examined on each filter.

For some studies, cells were transfected by electroporation to express CA-MEK1 and green fluorescent protein (GFP) or GFP alone. The plasmids were introduced at a ratio of 4:1 (CA-MEK1/GFP). This protocol yields cotransfection efficiencies of nearly 100\% (Nguyen et al., 1999). Thus, migration of CA-MEK-expressing cells could be studied in isolation by counting green-fluorescent cells on the membrane surfaces. Cells were added to Transwell chambers $24 \mathrm{~h}$ after transfection. Migration was allowed to proceed as described above. At the end of experiments, the cells were fixed with paraformaldehyde, costained with DAPI, and examined by fluorescence microscopy.

Cell death studies. Primary cultures of Schwann cells transfected with NTC siRNA or LRP-1-specific siRNA were plated at 10,000 cells per well in 96-well plates coated with $10 \mu \mathrm{g} / \mathrm{ml}$ fibronectin. Cells were cultured overnight in complete medium. The cells were then either retained in complete medium, re-equilibrated in DMEM containing 0.5\% FBS, or cultured in Sato media (Bottenstein and Sato, 1980) for $4 \mathrm{~h}$. Cell death was measured using the Cell Death ELISA (Roche), a colorimetric assay that measures the amount of intracytoplasmic oligonucleosomes (Campana et al., 2006).

Animal surgeries. Experiments were performed using adult male Sprague Dawley rats $(200 \mathrm{~g})$ from Harlan Laboratories, which were housed in pairs with a $12 \mathrm{~h}$ light/dark cycle and ad libitum access to food and water. For surgery, rats were anesthetized with $2 \%$ isoflurane (IsoSol; VedCo). Animals were killed by intraperitoneal injection of an overdose of anesthetic mixture containing ketamine $(100 \mathrm{mg} / \mathrm{kg}$; Phoenix Scientific) and xylazine $(10 \mathrm{mg} / \mathrm{kg}$; Boerhinger Pharmaceutical) followed by cervical dislocation. All procedures were performed according to protocols approved by the University of California, San Diego Committee on Animal Research, and conform to the National Institutes of Health guidelines for animal use.

Using a sterile field, the left sciatic nerve was crushed once for $2 \mathrm{~s}$ at the sciatic nerve notch, using flat forceps (Myers et al., 2003). The muscle layer then was closed using 6.0 silk sutures, followed by the skin. Twentyfour hours later, when Schwann cell LRP-1 expression is substantially increased (Campana et al., 2006), rats were re-anesthetized and injected with $1.0 \mu \mathrm{l}$ of MMP-9-PEX or GST $(5 \mu \mathrm{M}$ stock $)+1 \mu \mathrm{l}$ of PBS $(n=$ 4/group) or with $1.0 \mu$ l of MMP-9-PEX $(5 \mu \mathrm{M})+1.0 \mu$ l of GST-RAP (25 


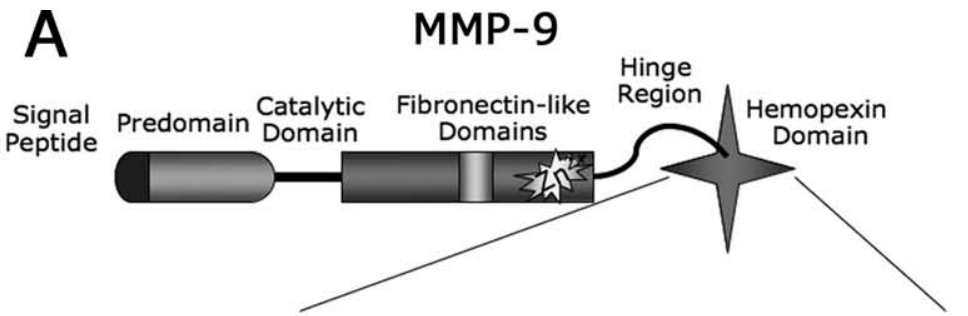

(514) dacnvnifdaiaeignqlyl......srselnqvdqvgyvtydilq (704)

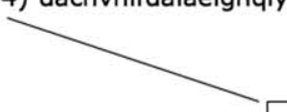

MMP-9-PEX

B

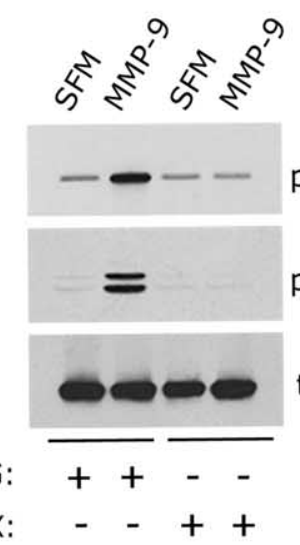

pERK1/2

total Akt

Control IgG anti-MMP-9-PEX:
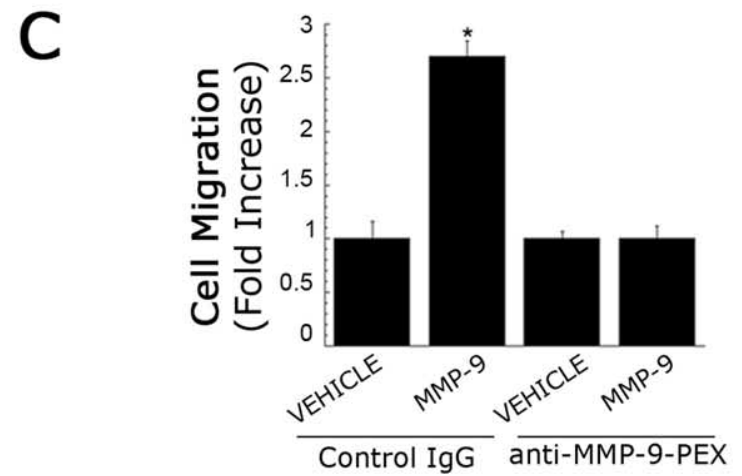

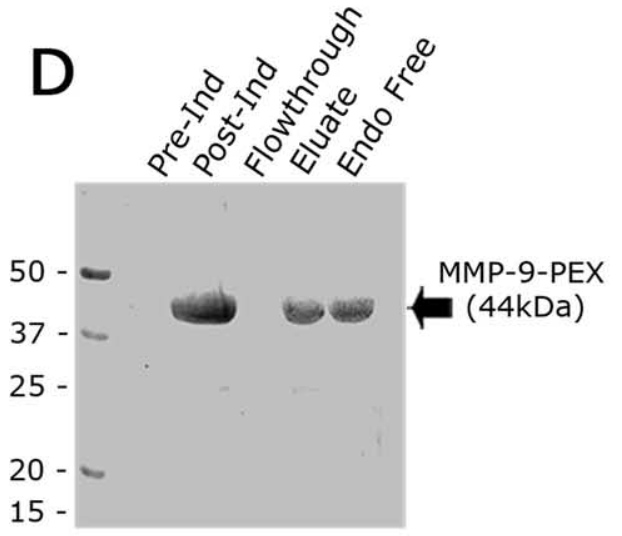

$\mathrm{kDa}$
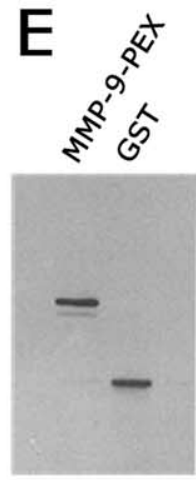

WB: anti-GST

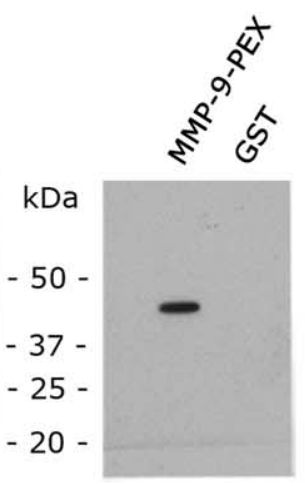

anti-MMP-9-PEX
Figure 5. Characterization of a GST-fusion protein encompassing the hemopexin domain/LRP-1-binding domain of MMP-9, MMP-9-PEX. A, Schematic diagram of MMP-9. Amino acids 514-704 are contained in GST-MMP-9-PEX. B, Immunoblot analysis of pAkt and pERK1/2 in Schwann cells that were pretreated for 15 min with nonspecific lgG or a monoclonal antibody that specifically recognizes the hemopexin domain in human MMP-9 (anti-MMP-PEX) in SFM and then with MMP-9 or NRG-1. Equal amounts of cellular protein $(50 \mu \mathrm{g})$ were loaded into each lane and subjected to SDS-PAGE and electrotransferred to nitrocellulose for detection with specific antibodies. Blots represent $n=2$. C, Quantification of Schwann cell migration after pretreatment with $\lg \mathrm{G}$ or anti-MMP-9-PEX and stimulation with MMP-9. Migration was allowed to proceed for $4 \mathrm{~h}$. Data are expressed as mean \pm $\mu \mathrm{M})(n=4)$ directly into the nerve fascicle at the crush injury site. Ten minutes later, nerve tissue distal and proximal to the injury site $(0.5$ $\mathrm{cm}$ ) was collected, together with the contralateral nerve. Uninjured rat sciatic nerves also were injected with $1.0 \mu \mathrm{l}$ of MMP9-PEX or GST $(5 \mu \mathrm{M}$ stock $)+1 \mu \mathrm{l}$ of PBS $(n=4$ /group $)$. Ten minutes later, nerve tissue was collected at the injection site $(0.5 \mathrm{~cm})$. Extracts of sciatic nerve were isolated in RIPA buffer for immunoblot analysis. For immunofluorescence microscopy studies (see below), rats were perfused transcardially with $4 \%$ paraformaldehyde in phosphate buffer $(0.1 \mathrm{~mol} / \mathrm{L}, \mathrm{pH} 7.4)$ before collecting sciatic nerve tissue.

Immunofluorescence microscopy analysis of crush-injured sciatic nerve. Distal sciatic nerve $(0.5 \mathrm{~cm})$ was recovered from rats that had been perfused transcardially. The resected tissue was immersed in the same fixative solution for $2 \mathrm{~h}$ at $4^{\circ} \mathrm{C}$ and then transferred to $20 \%$ sucrose in PBS overnight. Serial $10 \mu \mathrm{m}$ sections were prepared using a cryostat and mounted on Superfrost Plus Micro Slides (VWR). Polyclonal primary antibody, specific for phosphorylated ERK1/2 (1:500), was applied overnight at $4^{\circ} \mathrm{C}$. After washing with Tris-buffered saline/Tween 20 three times, the sections were incubated with Alexa Fluor 488-conjugated goat anti-rabbit $\operatorname{IgG}$ antibody $(5 \mu \mathrm{g} / \mathrm{ml})$ for $1 \mathrm{~h}$. In control studies, the primary antibody was omitted; no specific immunoreactivity was observed. Nuclei were stained with mounting medium containing DAPI (Invitrogen). All slides were coverslipped and visualized using a Leica microscope equipped with a DFC300 digital camera and Open Laboratory software.

Statistical analysis. In all experiments, replicates refer to separate experiments, typically performed with internal duplicates or triplicates. Results of cell migration, cell death, and in vivo cell-signaling experiments were subjected to ANOVA. Tukey's post hoc analysis was used to assess differences between treatment groups.

\section{Results \\ MMP-9 activates cell signaling by} binding LRP-1

MMP-9 is a major regulator of the response to PNS injury (La Fleur et al., 1996), which is known to bind LRP-1 (Hahn-Dantona et al., 2001). Because LRP-1 ligands are reported to activate cell signaling (Hu et al., 2006; Mantuano et al., 2008), we investigated the effects of MMP-9 on cell signaling in primary cul-

\section{$\leftarrow$}

SEM $(n=2),{ }^{*} p<0.01$ compared with respective vehicle controls. D, Purification and characterization of MMP-9-PEX. Aliquots of different fractions ( $50 \mu \mathrm{g}$ ) were separated by SDSPAGE and stained with Coomassie Blue. Ind, Induction; Endo, endotoxin. $\boldsymbol{E}$, Immunoblot analysis of GST-MMP-9-PEX (1 $\mu \mathrm{g})$. Blots were incubated with either a rabbit polyclonal antibody against GST or with a monoclonal antibody that targets the hemopexin domain of MMP-9. 
tures of Schwann cells. Figure $1 A$ shows that MMP-9 (100 nM) activated Akt and ERK1/2. Activation of cell signaling by MMP-9 was sustained for at least $2 \mathrm{~h}$. In studies that are not shown, we varied the concentration of MMP-9 and demonstrated activation of Akt and ERK/MAP kinase with concentrations as low as $1 \mathrm{nM}$. To estimate the degree of activation of ERK1/2 and Akt in MMP9-treated Schwann cells, we compared the response to that observed with NRG-1, a potent activator of ERK1/2 (Meintanis et al., 2001). Figure $1 B$ shows that MMP-9 and NRG-1 activated ERK1/2 and Akt similarly. This result was confirmed by densitometry (Fig. 1C). In contrast, matrix metalloproteinase-2 (MMP-2), which binds to LRP-1 but only indirectly as part of a complex with thrombospondin (Emonard et al., 2004), failed to activate cell signaling in Schwann cells (Fig. $1 B$ ).

To test whether LRP-1 is responsible for the effects of MMP-9 on cell signaling, we pretreated Schwann cells with GST-RAP, a well-established LRP-1 antagonist that binds to LRP-1 and precludes binding of other ligands (Willnow et al., 1996; Strickland et al., 2002), or with GST, as a control. The cells were then stimulated with MMP-9. When added alone, GST-RAP did not activate cell signaling (Fig. $1 D$ ), confirming results obtained in diverse cell types (Bacskai et al., 2000; Mantuano et al., 2008); however, GST-RAP completely blocked phosphorylation of Akt and ERK1/2 in response to MMP-9. The effects of GST-RAP on MMP-9-initiated cell signaling were specific because GST-RAP failed to inhibit activation of Akt or ERK1/2 in response to NRG-1 (Fig. 1E).

Because GST-RAP may antagonize interactions involving LDL receptor homologues in addition to LRP-1 (Strickland et al., 2002), we applied LRP-1 gene silencing to further assess the function of LRP-1 in MMP-9-initiated cell signaling. Schwann cells were transfected with rat LRP-1-specific siRNA or with NTC siRNA, as previously described (Campana et al., 2006). The cells were then treated with MMP-9 or with Epo, a previously described activator of ERK1/2 in Schwann cells that binds to the Epo receptor and not LRP-1 (Li et al., 2005). In cells transfected with NTC siRNA, Epo and MMP-9 activated Akt and ERK1/2 similarly (Fig. 1F). In cells transfected with LRP-1-specific siRNA, Epo still activated ERK 1/2, as anticipated; however, the response to MMP-9 was blocked. Together, our LRP-1 gene silencing and RAP competition studies demonstrate that MMP-9 induces cell signaling by an LRP-1-dependent mechanism.

MMP-9-binding to LRP-1 promotes Schwann cell migration Next, we tested whether MMP-9 promotes Schwann cell migration. Cells were added to Transwell chambers in Sato medium, to optimize survival (Bottenstein and Sato, 1980). FBS (10\%) was added to the bottom compartment to generate a chemotactic gradient. To assess the activity of LRP-1, GST-RAP or GST were added to both chambers. Figure 2 shows that in the presence of GST (the control), MMP-9 increased Schwann cell migration 2.5 -fold $(p<0.01)$. Equivalent results were obtained when vehicle was added instead of GST (results not shown). The magnitude of the increase in cell migration induced by MMP-9 was similar to that observed with NRG-1. GST-RAP had a modest but significant effect on Schwann cell migration in the absence of agonists ( $40 \pm 9 \%$ reduction, $p<0.05$, see bar labeled "vehicle"); however, in the presence of GST-RAP, NRG-1 still increased Schwann cell migration by approximately fourfold $(p<0.01)$. In contrast, GST-RAP completely blocked Schwann cell migration in response to MMP-9. MMP-2 did not regulate Schwann cell migration in the presence or absence of GST-RAP.

As a second approach to study the role of LRP-1 in MMP-9-
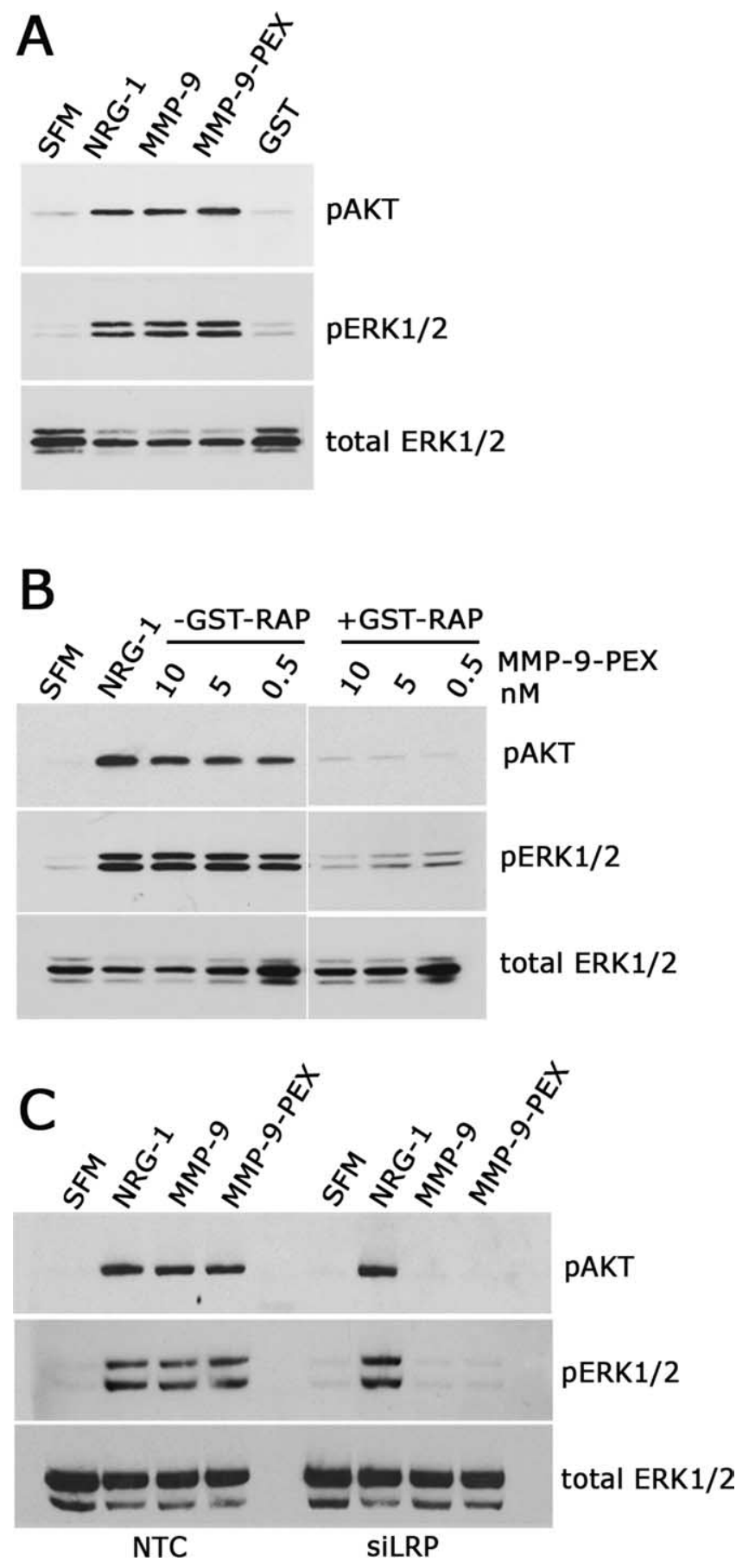

Figure 6. Immunoblot analysis of pAkt and pERK1/2 after treatment with MMP-9-PEX in LRP-1-inhibited and control cells. A, Primary Schwann cells treated with NRG-1 (0.2 nM), MMP-9 (10 nM), or MMP-9-PEX (10 nM) for $10 \mathrm{~min}$. B, Primary Schwann cells pretreated with GST-RAP (100 nm) for $15 \mathrm{~min}$ before MMP-9-PEX (0-10 nM) for $10 \mathrm{~min}$. C, Primary Schwann cells were transfected with NTC siRNA or LRP-1-specific siRNA. Cells were treated with NRG-1, MMP-9 or MMP-9-PEX for $10 \mathrm{~min}$. All cells were solubilized in RIPA buffer supplemented with sodium orthovanadate and proteinase inhibitors. Equal amounts of cellular protein $(50 \mu \mathrm{g})$ were loaded into each lane and subjected to SDS-PAGE and electrotransferred to nitrocellulose for detection with specific antibodies. Each blot represents at least three independent studies.

promoted Schwann cell migration, we examined cells in which LRP-1 was silenced. Control cells, which were transfected with NTC siRNA, migrated similarly to nontransfected cells, in the absence of agonists and after treatment with MMP-9 or NRG-1 (Fig. 3). LRP-1 gene silencing inhibited the basal rate of Schwann 

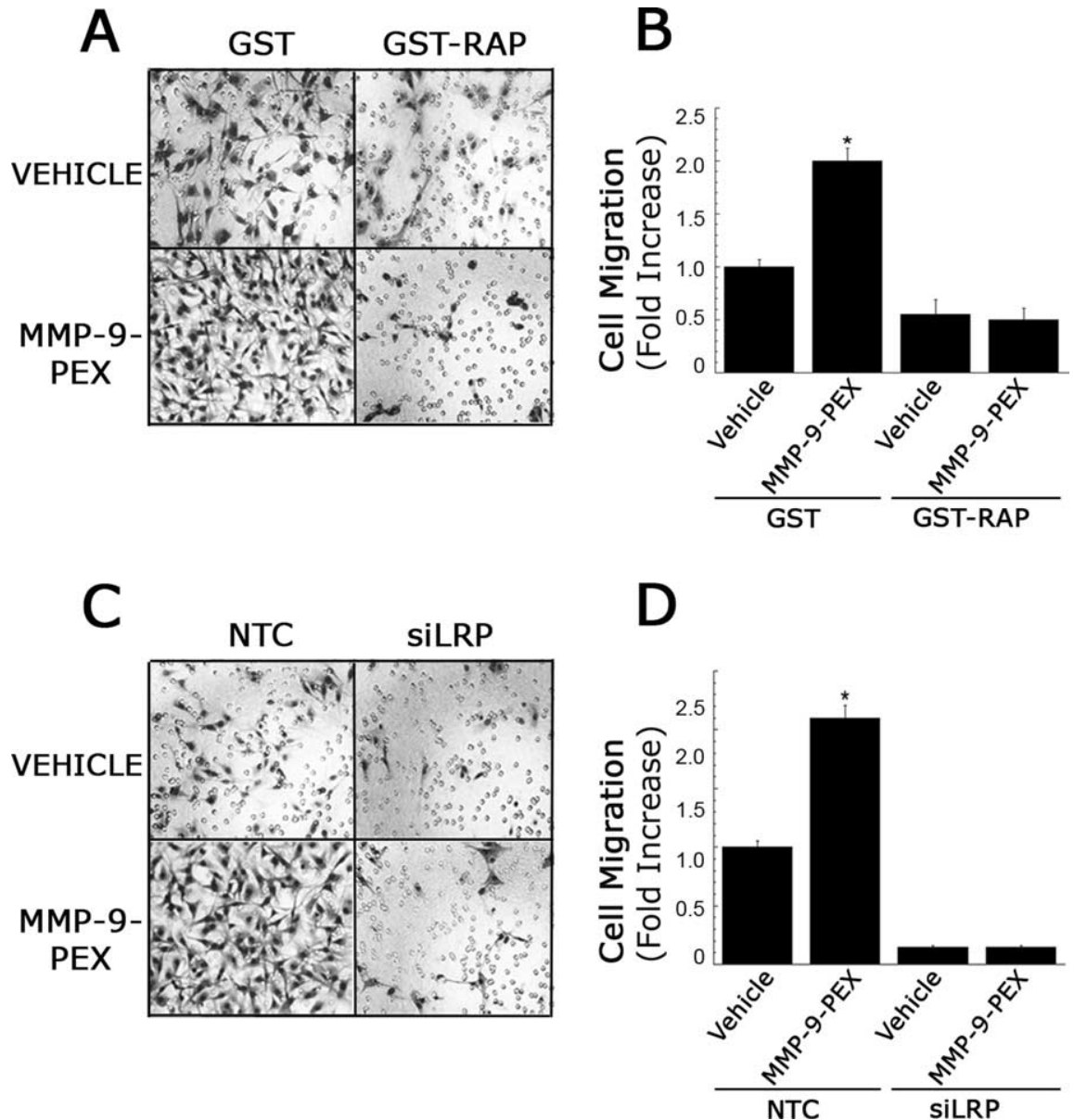

Figure 7. MMP-9-PEX promotes Schwann cell migration that is blocked by the LRP- 1 antagonist, GST-RAP, and by LRP-1 gene silencing. $A$, Images of Schwann cells which migrated to the underside surface of Transwell membranes. Cells were pretreated with GST or GST-RAP (100 nM) before the addition of MMP-9-PEX (10 nM). Migration was allowed to proceed for $4 \mathrm{~h}$. $\boldsymbol{B}$, Quantification of cell migration results. Data are expressed as mean $\pm \operatorname{SEM}(n=6),{ }^{*} p<0.01$ compared with respective vehicle controls. C, Images of Schwann cells transfected with NTC- or LRP-1-specific siRNA, which migrated to the underside surface of Transwell membranes. The cells were treated with MMP-9-PEX or vehicle. Migration was allowed to proceed for $4 \mathrm{~h}$. D, Quantification of cell migration results. Data are expressed as mean $\pm \operatorname{SEM}(n=6),{ }^{*} p<0.01$ compared with respective vehicle controls.

cell migration by $85 \%$ in the absence of agonists (Fig. 3) $(p<$ $0.01)$. Nevertheless, NRG-1 strongly promoted migration of cells in which LRP-1 was silenced. In contrast, no increase in cell migration was observed when LRP-1-silenced cells were treated with MMP-9, confirming the results obtained with GST-RAP. Thus, LRP-1 is necessary to mediate the effects of MMP-9 on Schwann cell migration.

Our experiments with RAP and LRP-1 gene silencing suggested that LRP-1 may regulate Schwann cell migration in the absence of added agonists. Because our previous results demonstrated a role for LRP-1 in Schwann cell survival (Campana et al., 2006), we performed control studies to assess the effects of LRP-1 gene silencing on Schwann cell survival under the conditions of our cell migration studies. Cells that were cultured in $0.5 \%$ FBSsupplemented DMEM for $4 \mathrm{~h}$ demonstrated a significant increase $(p<0.05)$ in cell death, compared with cells in complete medium, as determined using the highly sensitive Cell Death ELISA (Fig. 3C). In contrast, cell death was not significantly increased when cells were cultured in Sato medium, which was used in our cell migration experiments. These results and the ability of LRP1 -silenced cells to respond vigorously to NRG-1 demonstrate that the effects of LRP-1 gene silencing on MMP-9-promoted Schwann cell migration are not caused by altered survival.
To test whether the effects of MMP-9 on cell signaling and cell migration are linked, first we studied Schwann cell migration in the presence of pharmacological inhibitors of MEK1 (PD98059) and PI3K (LY294002). Neither inhibitor significantly affected cell migration in the absence of MMP-9; however, in the presence of MMP-9, both inhibitors independently decreased cell migration to the level observed in the absence of MMP-9 (Fig. 4). These results suggest that activated ERK1/2 and PI3K are necessary for MMP9-promoted Schwann cell migration.

The LRP-1-binding domain in MMP-9 replicates the activity of MMP-9 MMP-9-binding to LRP-1 is mediated by the hemopexin domain (MMP-9-PEX) (Van den Steen et al., 2006), which is shown in relation to the overall structure of MMP-9 in Figure 5A. When Schwann cells were treated with MMP-9, after preincubation for 15 min with MMP-9-PEXspecific antibody, activation of Akt and ERK1/2 was blocked (Fig. 5B). Nonspecific IgG had no effect on MMP-9initiated cell signaling. Furthermore, the MMP-9-PEX-specifc antibody had no effect on cell signaling in response to NRG-1, confirming that the effects of the antibody on MMP-9-initiated cell signaling were specific. MMP-9-PEX-specific antibody also inhibited Schwann cell migration in response to MMP-9 without affecting the basal rate of cell migration, consistent with its effects on MMP-9initiated cell signaling (Fig. 5C).

Because the proteinase active site introduces multiple possibilities regarding the mechanism by which MMP-9 stimulates cell signaling and cell migration, we expressed the isolated hemopexin domain $\left(\right.$ Asp $^{514}-\mathrm{Cyc}^{704}$ ) as a GST-fusion protein (MMP-9-PEX), which was purified by affinity chromatography. SDS-PAGE and Coomassie staining revealed a single product with the predicted molecular mass of $44 \mathrm{kDa}$ (Fig. 5D). Immunoblot analysis of MMP-9-PEX, using polyclonal antisera specific for GST or the MMP-9-PEX, also identified a single product with the predicted molecular mass (Fig. 5E).

MMP-9-PEX activated ERK1/2 and Akt in Schwann cells (Fig. $6 A$ ). The magnitude of the response was equivalent to that observed with intact MMP-9. Figure $6 B$ shows that low concentrations of MMP-9-PEX were active in cell signaling (Fig. 6B). Cell signaling in response to MMP-9-PEX was inhibited by GST-RAP (Fig. $6 \mathrm{~B}$ ) and blocked by LRP-1 gene silencing (Fig. 6C). In contrast, NRG-1 activated Akt and ERK1/2 equivalently in LRP-1 gene-silenced and control cells. Thus, the effects of LRP-1 gene silencing on MMP-9-PEX-initiated cell signaling were specific. Together, these results indicate that MMP-9-PEX activates cell signaling by an LRP-1-dependent pathway in Schwann cells, which is equivalent to that activated by intact MMP-9.

Next, we tested the effects of MMP-9-PEX on Schwann cell migration. Figure 7 shows that MMP-9-PEX increased cell mi- 
gration approximately twofold ( $p<0.05)$. The effects of MMP9-PEX on cell migration were blocked by GST-RAP and by LRP-1 gene silencing. Thus, MMP-9-PEX promotes Schwann cell migration by an LRP-1-dependent pathway, as was observed with intact MMP-9. LY294002 and PD98059 inhibited the effects of MMP-9-PEX on Schwann cell migration (Fig. 8A,B). Thus, the activity of MMP-9-PEX in cell migration appeared to be related to its ability to stimulate cell signaling, consistent with the results obtained using intact MMP-9.

Activation of ERK1/2 is associated with a promigratory phenotype in multiple cell types (Klemke et al., 1997; Nguyen et al., 1999; Lester et al., 2005). To determine whether ERK1/2 activation promotes Schwann cell migration, we transfected Schwann cells to express CA-MEK1. Cells were cotransfected to express GFP so that the transfected population could be studied in isolation. Figure $8 C$ shows that in the absence of exogenously added ligands, CA-MEK-1-expressing Schwann cells demonstrated significantly increased cell migration compared with cells that expressed GFP alone $(p<0.05)$. MMP-9-PEX promoted migration of GFP-expressing cells (no CA-MEK1) so that the level of migration was equivalent to that observed with untreated CAMEK1-expressing cells. However, when CA-MEK1-expressing cells were treated with MMP-9-PEX, cell migration was unchanged. These results indicate that activation of ERK $1 / 2$ by MMP-9-PEX is sufficient to explain the activity of this agent in cell migration. When ERK1/2 is already optimally activated, MMP-9-PEX demonstrates no further activity.

MMP-9-PEX activates cell signaling in injured sciatic nerves by binding to LRP-1

Because MMP-9-PEX activates cell signaling and promotes Schwann cell migration by binding to LRP-1 in vitro, we undertook studies to examine the effects of MMP-9-PEX on Akt and ERK1/2 in vivo, in uninjured and crush-injured sciatic nerves. Intact MMP-9 was not studied to limit the number of possible mechanisms by which cell signaling may be regulated. MMP-9PEX was injected directly into the uninjured sciatic nerve or into sciatic nerves $24 \mathrm{~h}$ after crush injury when Schwann cell LRP-1 is substantially upregulated distal to the crush site (Campana et al., 2006; Gaultier et el., 2008). Figure 9A shows that MMP-9-PEX did not activate Akt or ERK1/2 in uninjured nerve. This result is consistent with our previous observation that Schwann cells express substantial levels of LRP-1 only after nerve injury (Campana et al., 2006). In contrast, MMP-9-PEX caused robust phosphorylation of both ERK1/2 and Akt in sciatic nerves $24 \mathrm{~h}$ after crush injury. When MMP-9-PEX was coinjected together with GST-RAP, activation of Akt and ERK1/2 was inhibited. Figure 9B shows densitometry results, summarizing the effects of MMP-9PEX and GST-RAP on ERK1/2 activation in multiple studies. GST-RAP caused a significant decrease $(p<0.05)$ in ERK1/2 activation in response to MMP-9-PEX in injured nerves.

As a second method to demonstrate that MMP-9-PEX activates ERK1/2 in Schwann cells in vivo, immunofluorescence microscopy studies were performed. We examined distal sciatic nerve, $24 \mathrm{~h}$ after crush injury and $10 \mathrm{~min}$ after injection of MMP9-PEX or GST (the control). At the time of examination, Schwann cells comprise $90 \%$ of the nucleated endoneural cells in the crush-injured distal nerve (Asbury and Johnson, 1978). Figure $9 C$ confirms our immunoblot analyses, demonstrating a substantial increase in overall immunopositivity for phosphorylated ERK1/2 in the endoneural space after treatment with MMP-9PEX (compared with GST). Numerous Schwann cell crescents demonstrated particularly robust immunopositivity in the
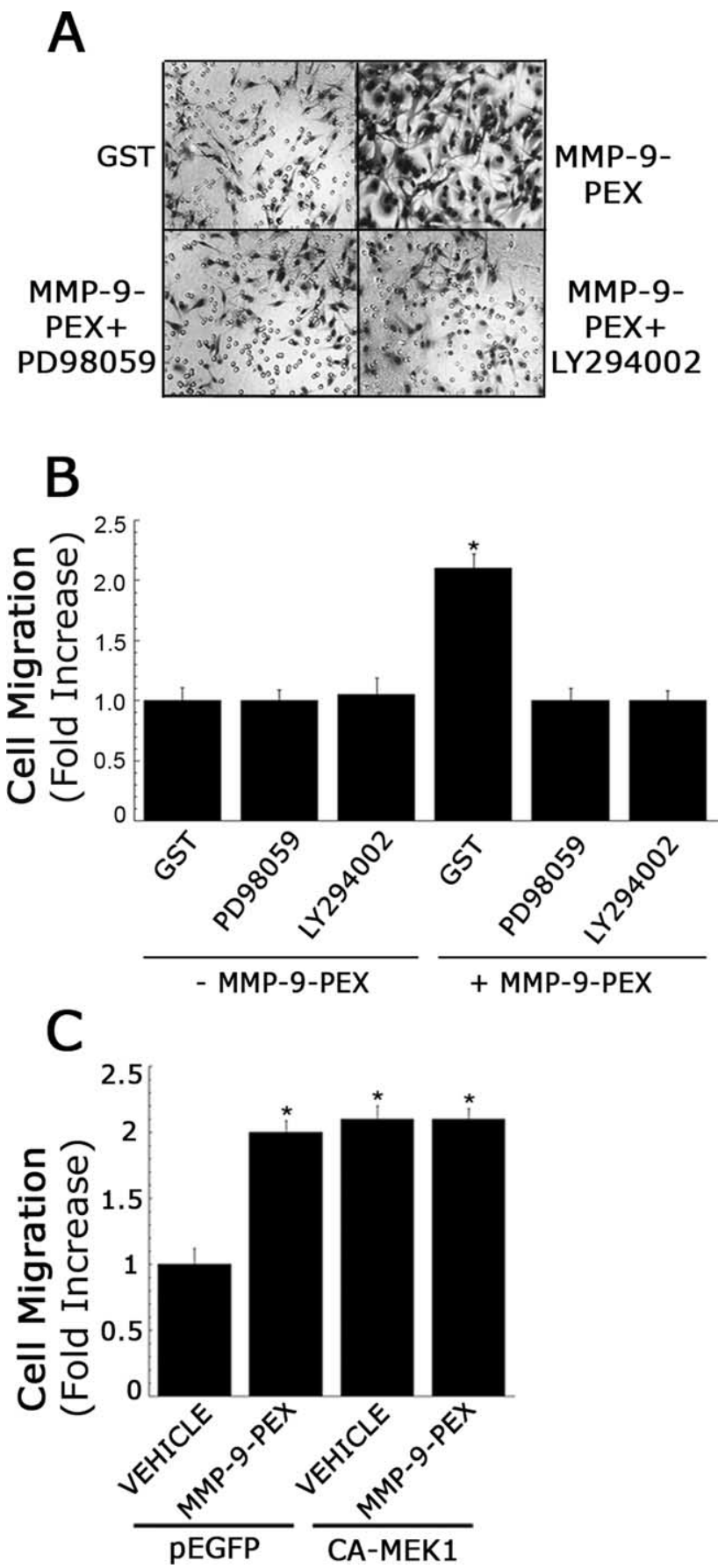

Figure 8. MMP-9-PEX-induced Schwann cell migration is blocked by inhibitors of MEK1 and PI3K. A, Images of Schwann cells that penetrated to the underside surface of Transwell mem-

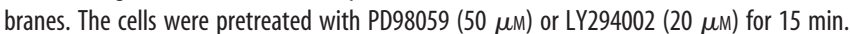
MMP-9-PEX (10 nм) was subsequently added. Migration was allowed to proceed for $4 \mathrm{~h}$. $\boldsymbol{B}$, Quantification of cell migration results. Data are expressed as mean $\pm \mathrm{SEM}(n=4)$. ${ }^{*} p<0.01$ compared with respective controls. C, MMP-9-PEX promotes Schwann cell migration by activating $p E R K 1 / 2$. Schwann cells were transfected with constitutively active MEK1 (CA-MEK) or empty vector (pEGFP). All cells were cotransfected with pEGFP to express GFP. Vehicle or MMP9-PEX was added. Cell migration proceeded for $4 \mathrm{~h}$. Migration was quantitated by counting green fluorescing-cells and expressed as a percentage of that observed with control cells that were transfected to express GFP only (mean $\pm \mathrm{SE}, n=2$ ).

MMP-9-PEX-treated nerves (Fig. 9, inset). These profiles, while present, were less abundant in controls. Thus, the increase in phosphorylated ERK1/2 in MMP-9-PEX-treated sciatic nerves reflected, at least in part, activation of cell signaling in Schwann cells. 

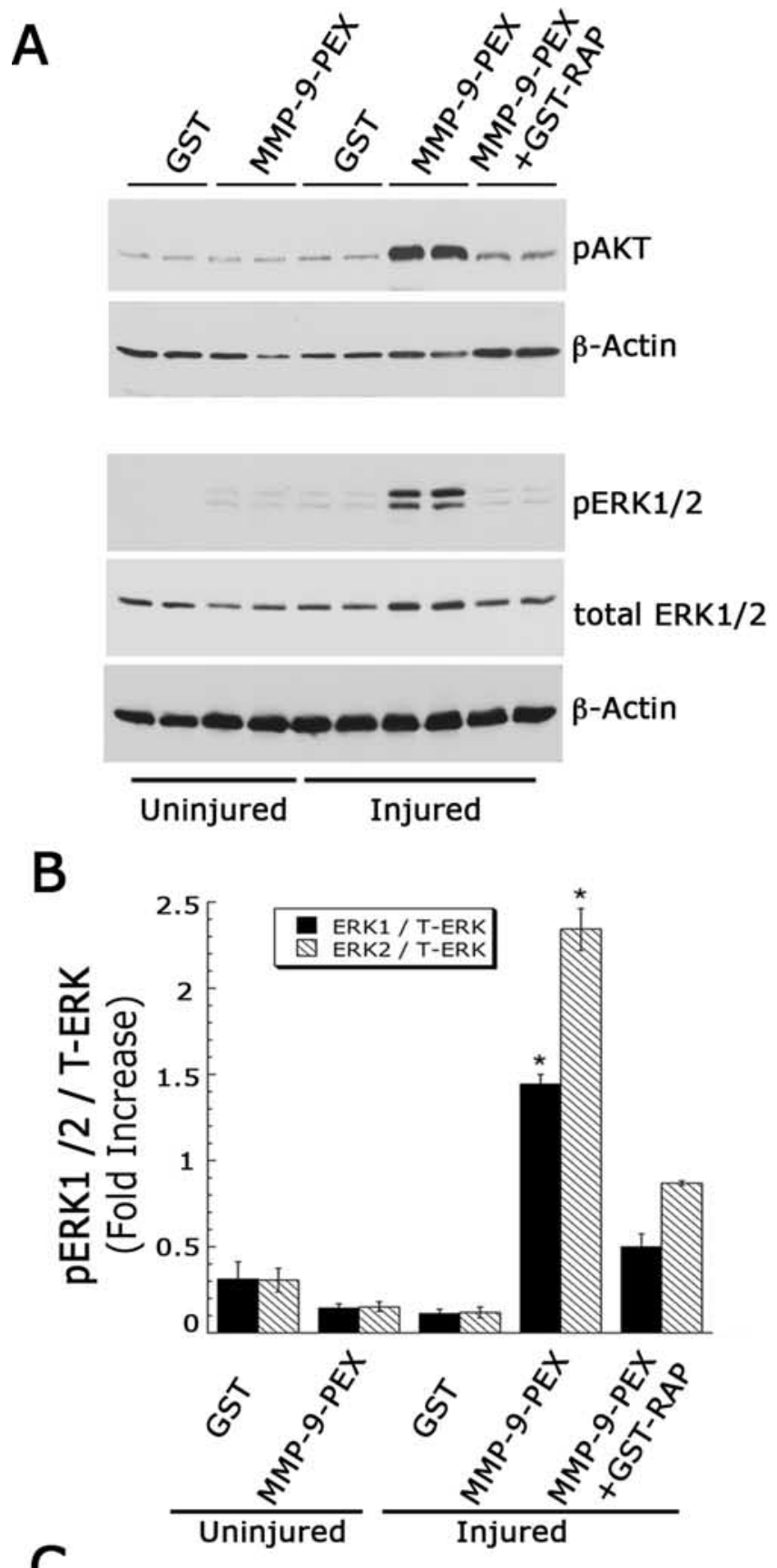

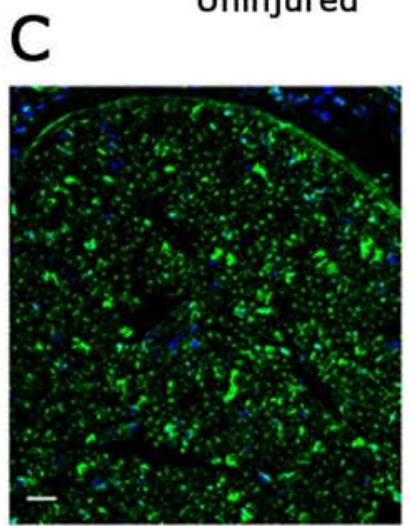

GST

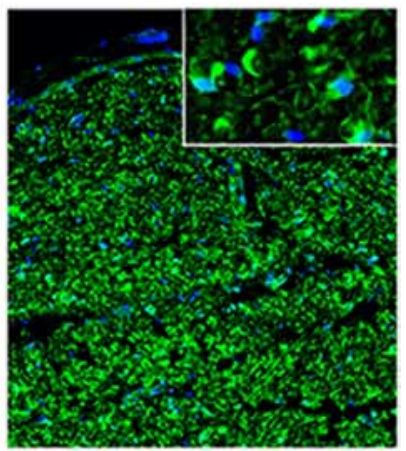

MMP-9-PEX
Figure 9. MMP-9-PEX activates cell signaling selectively in injured sciatic nerve by binding to LRP-1. A, Immunoblot analysis of pAkt and pERK1/2 in uninjured or crush-injured rat sciatic nerves injected with $2 \mu$ l of MMP-9-PEX, GST, or MMP-9-PEX + GST-RAP. Nerves were isolated

\section{Discussion}

Although resting Schwann cells in rodents may express low levels of LRP-1, expression of LRP-1 by Schwann cells is substantially increased in PNS injury (Campana et al., 2006; Gaultier et al., 2008). This is coincident with upregulation of Schwann cell MMP-9 expression (La Fleur et al., 1996; Shubayev and Myers, 2002). At the same time, Schwann cells undergo significant changes in phenotype (Jessen and Mirsky, 2005), dedifferentiating and gaining an increased capacity for migration, which is essential for the response to injury and regeneration (Anton et al., 1994; Torigoe et al., 1996; Chen and Zochodne, 2002). Primary cultures of Schwann cells are thought to most accurately model the physiology of Schwann cells in severely injured and/or denervated peripheral nerves (Jessen et al., 1990). Exposure of cultured Schwann cells to tumor necrosis factor- $\alpha$ substantially increases LRP-1 expression in vitro (Campana et al., 2006). Thus, understanding the function of Schwann cell LRP-1 is an important goal.

Our previous studies demonstrated a role for Schwann cell LRP-1 in cell survival in vivo and in vitro (Campana et al., 2006). We also have shown that LRP-1 may be shed from the Schwann cell plasma membranes, forming a soluble product similar to that previously identified in human blood (Quinn et al., 1997). Shed LRP-1 expresses anti-inflammatory activity, inhibiting the response of cells to tumor necrosis factor- $\alpha$ (Gaultier et al., 2008). In this study, we demonstrated for the first time that membraneassociated LRP-1 functions as a cell-signaling receptor for MMP-9 in Schwann cells and thereby regulates Schwann cell migration. Thus, Schwann cell LRP-1 emerges as a receptor that may control multiple aspects of the Schwann cell response to injury in the PNS.

The ability of MMP-9 to activate Akt and ERK1/2 in Schwann cells was blocked by RAP or by LRP-1 gene silencing. Thus, LRP-1 is essential for MMP-9-initiated cell signaling. Although we did not directly prove that MMP-9 binds directly to LRP-1 to trigger cell signaling, others have shown that the interaction of MMP-9 with LRP-1 is indeed direct (Van den Steen et al., 2006). Other proteins that have been reported to trigger cell signaling by binding to LRP-1 in various cell types include tPA, apolipoprotein E, and activated $\alpha_{2}$-macroglobulin (Hu et al., 2006; Hayashi et al., 2007; Padmasekar et al., 2007; Mantuano et al., 2008). Of these ligands, only $\alpha_{2}$-macroglobulin has been previously reported to stimulate cell signaling in Schwann cells (Mantuano et al., 2008). Like MMP-9, $\alpha_{2}$-macroglobulin activates both Akt and ERK1/2. Thus, these factors appear to be regulated downstream of LRP-1 in response to distinct ligands. In a previous study, we showed that LRP-1 gene silencing in Schwann cells decreases the basal level of activated Akt observed in the absence of added reagents (Campana et al., 2006). Although the equivalent result was not demonstrated here, our immunoblotting experiments were designed to detect more robust responses to added reagents,

$\leftarrow$

after $15 \mathrm{~min}$. Injured nerves were injected $24 \mathrm{~h}$ after crush injury. Equal amounts of nerve protein $(30 \mu \mathrm{g})$ were loaded into each lane and subjected to SDS-PAGE and electrotransferred to nitrocellulose for detection with specific antibodies. Each blot shows two rats per treatment. $\beta$-Actin or total ERK1/2 was used as loading control. $\boldsymbol{B}$, Quantification of phosphorylated ERK $1 / 2$ to total ERK1/2 ratios by densitometry ( $n=4-6$ rats), ${ }^{*} p<0.01$ compared with MMP-9-PEX + GST-RAP. C, Immunofluorescence microscopy for pERK1/2 in crush-injured rat sciatic nerves. The nerves were injected with GST or MMP-9-PEX $24 \mathrm{~h}$ after crush injury. Transcardial perfusion was initiated 15 min later. Images are at $100 \times$ magnification (scale bar, 100 $\mu \mathrm{m})$. Note pERK1/2 immunoreactivity (green) in Schwann cell crescents (670× magnification). DAPI (blue) identifies nuclei in the nerve fiber. Images represent $n=4$ per treatment. 
such as MMP-9 or NRG-1. Together, our previous and current results suggest that in the absence of added reagents, Schwann cells may establish autocrine cell-signaling pathways involving endogenously produced LRP-1 ligands that control Akt activation. Many LRP-1 ligands have been shown previously to regulate the response to PNS injury (Boyles et al., 1989; Arandjelovic et al., 2007; Sachs et al., 2007); however, not all LRP-1 ligands stimulate cell signaling, as evidenced by the lack of response to RAP. Understanding LRP-1-dependent and -independent pathways by which proteins that bind to LRP-1 function in the injured PNS is a goal for future investigation.

tPA activates ERK1/2 in an LRP-1-dependent manner in fibroblasts (Hu et al., 2006). Interestingly, the enzyme active site of tPA was not necessary for initiation of LRP-1-dependent cell signaling. To test whether the proteinase active site of MMP-9 is required for cell signaling, we constructed a GST-fusion protein encompassing only the hemopexin domain of MMP-9 (MMP-9PEX), which includes the binding site for LRP-1 (Van den Steen et al., 2006). MMP-9-PEX activated Akt and ERK1/2 in Schwann cells, replicating the effects of MMP-9. These results argue against a mechanism of MMP-9-initiated cell signaling that requires the MMP-9 catalytic domain or proteolysis of other membrane proteins, such as may be required for receptor transactivation events (Roelle et al., 2003).

The function of MMP-9 as a proteinase, which cleaves specific targets in the ECM to facilitate cell migration has received considerable attention (Heissig et al., 2005), although the importance of MMP-9, as opposed to other proteinases such as MT1-MMP, has been contested (Sabeh et al., 2004). In PNS injury, MMP-9 has been reported to promote Schwann cell dissociation from basement membranes, favoring reversion to the proliferative phenotype and establishment of new axonal connections (Neuberger and De Vries, 1992). Such activity seems complementary with the direct receptor-mediated interaction described here. By its effects inside and outside the cell, MMP-9 may orchestrate processes involved in Schwann cell migration and remodeling of the injured nerve microenvironment. The proteolytic activity of MMP-9 is tightly regulated by its endogenous inhibitor, TIMP-1, which also is expressed at increased levels by Schwann cells after injury (La Fleur et al., 1996). It is thought that TIMP-1 may counteract MMP-9 in basement membrane remodeling, thus providing balance and control (Matrisian, 1992; La Fleur et al., 1996). Complex formation between MMP-9 and TIMP-1 does not block the interaction with LRP-1 (Hahn-Dantona et al., 2001). Thus, it will be important to determine the role of TIMP-1 in regulating the effects of MMP-9 on Schwann cell signaling in future experiments.

PI3K and ERK1/2 have been implicated in Schwann cell migration before (Cheng et al., 2000; Meintanis et al., 2001). Pharmacologic inhibitors of ERK1/2 activation and PI3K blocked the increase in Schwann cell migration observed with MMP-9 or MMP-9-PEX. Although these results indicate that PI3K and ERK1/2 are required for MMP-9-promoted cell migration, they do not necessarily imply that both factors must be activated above the basal level. Instead, our studies with CA-MEK1 suggest that activation of ERK1/2 is most important for increased Schwann cell migration after MMP-9 treatment. Because MMP-9-PEX failed to further increase cell migration in CA-MEK1-expressing cells, the basal level of PI3K may be necessary together with ERK1/2 activation to promote Schwann cell migration. Activation of ERK1/2 and its intracytoplasmic target, myosin light chain kinase, has been implicated in the pathway by which multiple agents stimulate cell migration (Klemke et al., 1997; Nguyen et al., 1999; Webb et al., 2004; Lester et al., 2005). Our results are consistent with previous studies showing that blocking ERK1/2 activation inhibits NRG-1-stimulated Schwann cell migration (Meintanis et al., 2001). Other cell-signaling factors that have been implicated in NRG-1-stimulated Schwann cell migration include the atypical Dock180-related guanine nucleotide exchange factor Dock7, the Rho GTPases, Rac1, CDC42 and c-Jun $\mathrm{N}$ terminal kinase (Yamauchi et al., 2008).

To test whether the interaction of MMP- 9 with LRP- 1 may be significant in activating cell signaling in vivo in the PNS, we injected MMP-9-PEX directly into sciatic nerves. Increased activation of Akt and ERK1/2 was observed only under conditions in which we previously demonstrated that LRP-1 expression by Schwann cells is substantially increased (Campana et al., 2006). The relationship between responsiveness to MMP-9-PEX and known changes in LRP-1 expression occurring during nerve injury argues in favor of LRP-1 functioning as the receptor responsible for MMP-9-PEX-initiated cell signaling in vivo. The ability of RAP to inhibit the response to MMP-9-PEX in vivo supports the conclusion. MMP-9-PEX was engineered to selectively model the LRP-1-binding domain of MMP-9 (Van den Steen et al., 2006). Thus, the likely role of a LRP-1 in mediating cell signaling in response to MMP-9-PEX in vivo does not rule out other mechanisms that also may be operational with full-length MMP-9. Furthermore, receptors in the LRP-1 gene family other than LRP-1 may function as MMP-9-binding sites and also be antagonized by RAP (Strickland et al., 2002). Receptors in this category, such as LRP-2, have not been studied in PNS injury. Finally, our results do not rule out the existence of coreceptors that may function with LRP-1 to mediate cell signaling in response to MMP-9 and MMP-9-PEX.

Other investigators have demonstrated that crush injury alone may be sufficient to activate ERK1/2 in the distal nerve (Agthong et al., 2006). Given the results presented here, LRP-1 emerges as a receptor that may mediate this effect, by binding endogenously produced MMP-9 or other ligands in the absence of injected reagents such as MMP-9-PEX. Although we did not observe a change in the basal state of phosphorylated Akt or ERK1/2 in crush-injured nerves that were injected with vehicle, our immunoblotting experiments were designed to include short exposure times that accommodate the robust response to MMP-9-PEX and thus, were not properly configured to detect endogenous endoneural cell signaling. Future studies will be necessary to assess the impact of endogenous LRP-1-dependent cell signaling in PNS injury and whether LRP-1 supports Schwann cell motility in the distal segment.

\section{References}

Agthong S, Kaewsema A, Tanomsridejchai N, Chentanez V (2006) Activation of MAPK ERK in peripheral nerve after injury. BMC Neuroscience $7: 45$.

Akassoglou K, Yu WM, Akpinar P, Strickland S (2002) Fibrin inhibits peripheral nerve remyelination by regulating Schwann cell differentiation. Neuron 133:861-875.

Anton ES, Weskamp G, Reichardt LF, Matthew WD (1994) Nerve growth factor and its low affinity receptor promote Schwann cell migration. Proc Natl Acad Sci U S A 91:2795-2799.

Arandjelovic S, Dragojlovic N, Li X, Myers RR, Campana WM, Gonias SL (2007) A derivative of the plasma proteinase inhibitor $\alpha 2$-macroglobulin regulates the response to peripheral nerve injury. J Neurochem 103:694-705.

Asbury AK, Johnson TC (1978) Pathology of peripheral nerve. Major Probl Pathol 9:1-311.

Bacskai BJ, Xia MQ, Strickland DK, Rebeck GW, Hyman BT (2000) The endocytic receptor protein LRP also mediates neuronal calcium signaling 
via N-methyl-D-aspartate receptors. Proc Natl Acad Sci U S A 97:11551-11556.

Blesch A, Tuszynski MH (2007) Transient growth factor delivery sustains regenerated axons after spinal cord injury. J Neurosci 27:10535-10545.

Bottenstein JE, Sato GH (1980) Fibronectin and polylysine requirement for proliferation of neuroblastoma cells in defined medium. Exp Cell Res 129:361-366.

Boyles JK, Zoellner CD, Anderson LJ, Kosik LM, Pitas RE, Weisgraber KH, Hui DY, Mahley RW, Gebicke-Haerter PJ, Ignatius MJ, Shooter EM (1989) A role for apoplipoprotein E, apolipoprotein A-I, and low density lipoproein receptors in cholesterol transport during regeneration and remyleination of the rat sciatic nerve. J Clin Invest 83:1015-1031.

Bunge RP, Bunge MB, Eldridge CF (1986) Linkage between axonal ensheathment and basal lamina production by Schwann cells. Annu Rev Neurosci 9:305-328.

Campana WM, Hiraiwa M, O'Brien JS (1998) Prosaptide activates the MAPK pathway by a G-protein-dependent mechanism essential for enhanced sulfatide synthesis by Schwann cells. FASEB J 12:307-314.

Campana WM, Darin SJ, O’Brien JS (1999) Phosphatidylinositol 3-kinase and Akt protein kinase mediate IGF-I- and prosaptide-induced survival in Schwann cells. J Neurosci Res 57:332-341.

Campana WM, Li X, Dragojlovic N, Janes J, Gaultier A, Gonias SL (2006) The low-density lipoprotein receptor-related protein is a prosurvival receptor in Schwann cells: possible implication in peripheral nerve injury. J Neurosci 26:11197-11207.

Cao C, Lawrence DA, Li Y, Von Arnim CA, Herz J, Su EJ, Makarova A, Hyman BT, Strickland DK, Zhang L (2006) Endocytic receptor LRP together with $\mathrm{PPA}$ and PAI-1 coordinates Mac-1 dependent macrophage migration. EMBO J 25:1860-1870.

Chen C, Zochodne DW (2002) In vivo proliferation, migration and phenotypic changes of Schwann cells in the presence of myelinated fibers. Neuroscience 115:321-329.

Cheng HL, Steinway ML, Russell JW, Feldman EL (2000) GTPases and phosphatidlyinositol-3-kinase are critical for insulin like growth factor I mediated Schwann cell motility. J Biol Chem 275:27194-27204.

Emonard H, Bellon G, Troeberg L, Berton A, Robinet A, Henriet P, Marbaiz E, Kirkegaard K, Patthy L, Eeckhout Y, Nagase H, Hornebeck W, Courtoy PJ (2004) Low density lipoprotein receptor related protein mediates endocytic clearance of Pr-MMP-2TIMP-2 complex through a thrombospondinindependent mechanism. J Biol Chem 279:54944-54951.

Gaultier A, Arandjelovic S, Li X, Janes J, Dragojlovic N, Zhou G, Dolkas J, Myers RR, Gonias SL, Campana WM (2008) A shed form of the low density lipoprotein receptor-related protein regulates peripheral nerve injury and pain. J Clin Invest 118:161-172.

Gotthardt M, Trommsdorff M, Nevitt MF, Shelton J, Richardson JA, Stockinger W, Nimpf J, Herz J (2000) Interactions of the low density lipoprotein receptor gene family with cytosolic adaptor and scaffold proteins suggest diverse biological functions in cellular communication and signal transduction. J Biol Chem 275:25616-25624.

Hahn-Dantona E, Ruiz JF, Bornstein P, Strickland DK (2001) The low density lipoprotein receptor-related protein modulates levels of matrix metalloproteinase- 9 by mediating its cellular catabolism. J Biol Chem 276:15498-15503.

Hayashi A, Koob JW, Liu DZ, Tong AY, Hunter DA, Parsadanian A, MacKinnon SE, Myckatyn TM (2007) A double transgenic mouse used to track migrating Schwann cells and regenerating axons following engraftment of injured nerves. Exp Neurol 207:128-138.

Heissig B, Rafii S, Akiyama H, Ohki Y, Sato Y, Rafael T, Zhu Z, Hicklin DJ, Okumura K, Ogawa H, Werb Z, Hattori K (2005) Low dose irradiation promotes tissue revascularization through VEGF release from mast cells and MMP-9 mediated progenitor cell mobilization. J Exp Med 202:739-750

Herz J, Goldstein JL, Strickland DK, Ho YK, Brown MS (1991) 39-kDa protein modulates binding of ligands to low density lipoprotein receptor-related protein $/ \alpha_{2}$-macroglobulin receptor. J Biol Chem 266:21232-21238.

Hu K, Yang J, Tanaka S, Gonias SL, Mars WM, Liu Y (2006) Tissue-type plasminogen activator acts as a cytokine that triggers intracellular signal transduction and induces matrix metalloproteinase-9 expression. J Biol Chem 281:2120-2127.

Ide C (1996) Peripheral nerve regeneration. J Neurosci Res 25:101-121.

Jessen KR, Mirsky R (2005) The origin and development of glial cells in peripheral nerves. Nat Rev Neurosci 6:671-682.
Jessen KR, Morgan L, Stewart HJ, Mirsky R (1990) Three markers of adult non-myelin forming Schwann cells, 217c (ran-1), A5E3 and GFAP: development and regulation by neuron and Schwann cell interactions. Development 109:91-103.

Kinoshita A, Whelan CM, Smith CJ, Mikhailenko I, Rebeck GW, Strickland DK, Hyman BT (2001) Demonstration by fluorescence resonance energy transfer of two sites of interaction between the low-density lipoprotein receptor-related protein and the amyloid precursor protein: role of the intracellular adapter protein Fe65. J Neurosci 21:8354-8361.

Klemke RL, Cai S, Giannini AL, Gallagher PJ, de Lanerolle P, Cheresh DA (1997) Regulation of cell motility by mitogen activated protein kinase. J Cell Biol 137:481-492.

Kowal RC, Herz J, Goldstein JL, Esser V, Brown MS (1989) Low density lipoprotein receptor-related protein mediates uptake of cholesteryl esters derived from apoprotein E-enriched lipoproteins. Proc Natl Acad Sci U S A 86:5810-5814.

Koyama Y, Naruo H, Yoshitomi Y, Munesue S, Kiyono S, Kusano Y, Hashimoto K, Yokoi T, Nakanishi H, Shimizu S, Okayama M, Oguri K (2008) Matrix metalloproteinase- 9 associated with heparan sulfate chains of GPI-anchored cell surface proteoglycans mediates motility of murine colon adenocarcinoma cells. J Biochem 143:581-592.

La Fleur M, Underwood JL, Rappolee DA, Werb Z (1996) Basement membrane and repair of injury to peripheral nerve: defining a potential role of macrophages matrix metalloproteinase and tissue inhibitor of metalloproteinases-1. J Exp Med 184:2311-2326.

Lauffenburger DA, Horwitz AF (1996) Cell Migration: a physically integrated molecular process. Cell 84:359-369.

Lester RD, Jo M, Campana WM, Gonias SL (2005) Erythropoietin promotes MCF-7 breast cancer cell migration by an ERK/mitogen activated protein kinase dependent pathway and is primarily responsible for the increase in migration observed in hypoxia. J Biol Chem 280:39273-39277.

Li X, Gonias SL, Campana WM (2005) Schwann cells express erythropoietin receptor and represent a major target for Epo in peripheral nerve injury. Glia 51:254-265.

Mantuano E, Mukandala G, Li X, Campana WM, Gonias SL (2008) Molecular dissection of the human $\mathrm{\alpha}_{2}$ macroglobulin subunit reveals domains with antagonistic activities in cell signaling. J Biol Chem 283:19904-19911.

Matrisian LM (1992) The matrix degrading metalloproteinases. Bioessays 14:455-463.

Meintanis S, Thomaidou D, Jessen K, Mirsky R, Matsas R (2001) The neuron-glia signal b-neuregulin promotes Schwann cell motility via the MAPK pathway. GLIA 34:39-51.

Myers RR, Sekiguchi Y, Kikuchi S, Scott B, Medicherla S, Protter A, Campana WM (2003) Inhibition of p38 MAP kinase activity enhances axonal regeneration. Exp Neurol 184:606-614.

Neuberger TJ, De Vries (1992) Axonal contact as a determinant of oligodendrocyte and Schwann cell function. In: Myelin biology and chemistry (Martenson RE, ed) pp173-193. Boca Raton, FL: CRC.

Nguyen DH, Catling AD, Webb DJ, Sankovic M, Walker LA, Somlyo AV, Weber MJ, Gonias SL (1999) Myosin light chain kinase functions downstream of Ras/ERK to promote migration of urokinase-type plasminogen activator stimulated cells in an integrin selective manner. J Cell Biol 146:149-164.

Orr AW, Elzie CA, Kucik DF, Murphy-Ullrich JE (2003) Thrombospondin signaling through the calreticulin/LDL receptor-related protein cocomplex stimulates random and directed cell migration. J Cell Sci 116:2917-2927.

Padmasekar M, Nandigama R, Wartenberg M, Schlüter KD, Sauer H (2007) The acute phase protein $\alpha_{2}$-macroglobulin induces rat ventricular cardiomyocyte hypertrophy via ERK1,2 and PI3 kinase Akt pathways. Cardiovasc Res 75:118-128.

Quinn KA, Grimsley PG, Dai YP, Tapner M, Chesterman CN, Owensby DA (1997) Soluble low density lipoprotein receptor related protein (LRP) circulates in human plasma 272:23946-23951.

Roelle S, Grosse R, Aigner A, Krell HW, Czubayko F, Gudermann T (2003) Matrix metalloproteinases 2 and 9 mediate epidermal growth factor receptor transactivation by gonadotropin-releasing hormone. J Biol Chem 278:47307-47318.

Sabeh F, Ota I, Holmbeck K, Birkedal-Hansen H, Soloway P, Balbin M, Lopez-Otin C, Shapiro S, Inada M, Krane S, Allen E, Chung D, Weiss SJ (2004) Tumor cell traffic through the extracellular matrix is controlled 
by the membrane anchored collagenase MT1-MMP. J Cell Biol 167:769-781.

Sachs BD, Baillie GS, McCall JR, Passino M, Schachtrup C, Wallace D, Dunlop AJ, MacKenzie KF, Klussmann E, Lynch MJ, Sikorski SL, Nuriel T, Tsigelny I, Zhang J, Houslay MD, Chao MV, Akassoglou K (2007) p75 neurotrophin receptor regulates tissue fibrosis through inhibition of plasminogen activation via a PDE4/camp/PKA pathway. J Cell Biol 177:1119-1132.

Shubayev VI, Myers RR (2002) Endoneurial remodeling by TNFalpha and TNFalpha releasing proteinases. A spatial and temporal co-localization study in painful neuropathy. J Periph Nerv Syst 7:179-182.

Springman EB, Angelton EL, Birkedal-Hansen H, Van Wart HE (1990) Multiple modes of activation of latent human fibroblast collagenase: evidence for the role of a Cys73 active-site zinc complex in latency and a "cysteine switch" mechanism for activation. Proc Natl Acad Sci U S A 87:364-368.

Strickland DK, Ashcom JD, Williams S, Burgess WH, Migliorini M, Argraves WS (1990) Sequence identity between the $\alpha_{2}$-macroglobulin receptor and low density lipoprotein receptor related protein suggests that this receptor is a multifunctional receptor. J Biol Chem 265:17401-17404.

Strickland DK, Gonias SL, Argraves WS (2002) Diverse roles for the LDL receptor family. Trends Endocrinol Metab 13:66-74.

Su HP, Nakada-Tsukui K, Tosello-Trampont AC, Li Y, Bu G, Henson PM, Ravichandran KS (2002) Interaction of CED-6/GULP, an adapter protein involved in engulfment of apoptotic cells with CED-1 and CD91/low density lipoprotein receptor-related protein (LRP). J Biol Chem 277:11772-11779.

Torigoe K, Tanaka HF, Takahashi A, Awaya A, Hashimoto K (1996) Basic behavior of migratory Schwann cells in peripheral nerve regeneration. Exp Neurol 137:301-308.

Van den Steen PE, Van Aelst I, Hvidberg V, Piccard H, Fiten P, Jacobsen C, Moestup SK, Fry S, Royle L, Wormald MR, Wallis R, Rudd PM, Dwek RA, Opdenakker G (2006) The hemopexin and O-glycosylated domains tune gelatinase B/MMP-9 bioavailability via inhibition and binding to cargo receptors. J Biol Chem 281:18626-18637.

Webb DJ, Wen J, Karns LR, Kurilla MG, Gonias SL (1998) Localization of the binding site for transforming growth factor-beta in human alpha2macroglobulin to a $20-\mathrm{kDa}$ peptide that also contains the bait region. J Biol Chem 273:13339-13346.

Webb DJ, Nguyen DH, Gonias SL (2000) Extracellular signal-regulated kinase functions in the urokinase receptor dependent pathway by which neutralization of low density lipoprotein receptor-related protein promotes fibrosarcoma cell migration and Matrigel invasion. J Cell Sci 113:123-134.

Webb DJ, Donais K, Whitmore LA, Thomas SM, Turner CE, Parsons JT, Horowitz AF (2004) FAK-Src signaling through paxillin, ERK and MLCK regulates adhesion disassembly. Nat Cell Biol 6:154-161.

Weiner JA, Chung J (1999) Schwann cell survival mediated by the signaling phospholipids lysophosphatidic acid. Proc Natl Acad Sci USA 96:5233-5238.

Willnow TE, Moehring JM, Inocencio NM, Moehring TJ, Herz J (1996) The low-density-lipoprotein receptor-related protein (LRP) is processed by furin in vivo and in vitro. Biochem J 313:71-76.

Yamauchi J, Miyamoto Y, Chan JR, Tanoue A (2008) ErbB2 directly activates the exchange factor Dock7 to promote Schwann cell migration. J Cell Biol 181:351-365. 